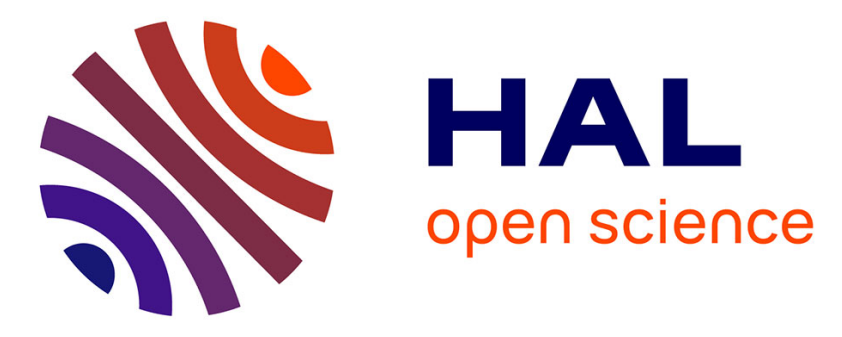

\title{
Microbial solubilisation of Cd from apatite during aerobic cellulose biodegradation
}

Cécile Quantin, S. Bruno Lartiges, Colette Munier-Lamy, Jaafar Ghanbaja, Jacques Yvonb, Jacques Berthelina

\section{- To cite this version:}

Cécile Quantin, S. Bruno Lartiges, Colette Munier-Lamy, Jaafar Ghanbaja, Jacques Yvonb, et al.. Microbial solubilisation of Cd from apatite during aerobic cellulose biodegradation. Agronomie, 2000, 20 (5), pp.557-565. 10.1051/agro:2000150 . hal-00886061

\section{HAL Id: hal-00886061 https://hal.science/hal-00886061}

Submitted on 1 Jan 2000

HAL is a multi-disciplinary open access archive for the deposit and dissemination of scientific research documents, whether they are published or not. The documents may come from teaching and research institutions in France or abroad, or from public or private research centers.
L'archive ouverte pluridisciplinaire HAL, est destinée au dépôt et à la diffusion de documents scientifiques de niveau recherche, publiés ou non, émanant des établissements d'enseignement et de recherche français ou étrangers, des laboratoires publics ou privés. 


\title{
Microbial solubilisation of $\mathrm{Cd}$ from apatite during aerobic cellulose biodegradation
}

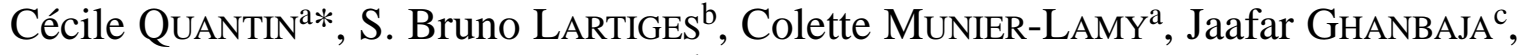 \\ Jacques YvON ${ }^{\mathrm{b}}$, Jacques BERTHELIN ${ }^{\mathrm{a}}$
}

\author{
${ }^{a}$ Centre de Pédologie Biologique, CNRS, FRE 2111 associée à l'Université Henri Poincaré, Nancy I, \\ 17 rue Notre-Dame des Pauvres, BP 5, 54501 Vandoeuvre-lès-Nancy Cedex, France \\ ${ }^{\mathrm{b}}$ Laboratoire Environnement et Minéralurgie, Pôle de l'Eau, 15 avenue du Charmois, BP 40, 54501 Vandoeuvre-lès-Nancy, France \\ ${ }^{\mathrm{c}}$ Service Commun de Microscopie Électronique à Transmission, Université Henri Poincaré, Nancy I, Faculté des Sciences, BP 239, \\ 54506 Vandoeuvre-lès-Nancy Cedex, France
}

(Received 29 September 1999; revised 7 April 2000; accepted 25 April 2000)

\begin{abstract}
Synthetic model sediments were used to investigate the processes of biological Cd solubilisation, during cellulose biodegradation in batch experiments under aerobic conditions. The model sediments consisted of a mixture of quartz sand, Cd-substituted or non-substituted hydroxyapatite and cellulose. The culture medium was inoculated with a mixed microflora and incubated under controlled conditions. After 53 days, cellulose biodegradation reached high rates for both sediments (34 to 37\% of initial carbon content) in the presence of microorganisms. Simultaneously, Cd release was significant and reached $34 \%$ of initial $\mathrm{Cd}$. Solubilisation of $\mathrm{Cd}$ and $\mathrm{Ca}$ was correlated with a $\mathrm{pH}$ decrease from 6.7 to 4.5 , and was thus a consequence of proton release in the solution. The use of model sediments allows assessment of biological weathering processes, particularly the influence of heterotrophic microorganisms in mineral solubilisation, and their involvement in the dispersion of trace elements in soils and sediments.
\end{abstract}

\section{cadmium / hydroxyapatite / microbial activity / model sediments / solubilisation}

Résumé - Solubilisation microbienne de $\mathbf{C d}$ au cours de la biodégradation aérobie de la cellulose. Des sédiments synthétiques ont été utilisés pour étudier les mécanismes de solubilisation biologique du cadmium d'une hydroxyapatite au cours de la biodégradation aérobie de cellulose. Les sédiments de synthèse sont constitués d'une matrice siliceuse, d'une hydroxyapatite substituée ou non en cadmium, et de cellulose. Ils ont été inoculés avec une communauté microbienne issue d'un sédiment naturel et incubés avec un milieu de culture en conditions contrôlées. La biodégradation de la cellulose est importante après 53 jours pour les deux sédiments (34 à $37 \%$ du carbone organique initial). Simultanément, la solubilisation de Cd est importante et atteint $34 \%$ du cadmium initialement présent. Cette solubilisation est associée à une acidification importante du milieu, le pH passant de 6,7 à 4,5. La solubilisation de Cd apparaît comme une conséquence de la production de protons dans le milieu.

Communicated by Isabelle Lamy

* Correspondence and reprints

quantin@cpb.cnrs-nancy.fr 
L'utilisation d'un tel système expérimental, simplifié, permet de définir les processus de dissolution et d'altération des minéraux impliquant l'activité de microorganismes hétérotrophes, et d'étudier leur implication dans la dispersion des éléments en traces dans les sols et les sédiments naturels.

cadmium / hydroxyapatite / activité microbienne / sédiments modèles / solubilisation

\section{Introduction}

River sediments and soils contain various mineral and organic phases that are reservoirs of trace elements [19]. Mobility and/or stability of trace elements depend on (i) their speciation, i.e. adsorbed on mineral surfaces, substituted in mineral phases, associated as complexes with organic matter, organised in small clusters or precipitates, etc., and on (ii) environmental conditions, i.e. $\mathrm{pH}$, redox potential, ionic strength, activity of microorganisms, etc. The knowledge of their speciation within sediments and soils is of crucial importance to provide a better understanding of their potential release in the environment and to determine risk assessment $[1,20$, 28].

Among trace elements, $\mathrm{Cd}$ is known as the most toxic and mobile element $[1,7,8,20-24]$. $\mathrm{Cd}$ is a naturally occurring element in the earth's crust where it is generally associated with $\mathrm{Zn}$ minerals and sulfide ores [7, 22]. It is thus naturally present in soils and sediments and can also be found as a contaminant introduced by anthropogenic activities such as agriculture (fertilisers), industry (smelters) and domestic waste disposal $[1,15,22,23]$. Cd behaviour is relatively well documented due to its persistence in the environment, its tendency to bioaccumulate and its toxicity to humans [22]. However, there are many situations in which $\mathrm{Cd}$ behaviour has not been studied, and where risk assessments have not been attempted yet [7, 20]. Such a situation is for instance encountered in the sediments of Lorraine's rivers (north-east of France). In this environment it was shown that calcium phosphates, sulfides, and iron oxyhydroxides represent the main trapping phases for trace elements [10]. As far as Cd is concerned, it is generally associated with hydroxyapatite where it substitutes for $\mathrm{Ca}$. Solubilisation of these phases then represents a potential hazard that must be investigated.
Microorganisms play an important role in the biogeochemical cycling of trace elements, as they are often involved in the weathering and/or formation of soil and sediment minerals, and as a consequence, in heavy metal behaviour $[4-6,9,12,13$, $18,26]$. However, except for autotrophic bacteria involved in oxidation and dissolution of heavy metal bearing sulfides [12], the role of heterotrophic microorganisms in heavy metal mobilisation has been largely overlooked $[6,11]$. This study addresses the problem of bioaccessibility and bioavailability of cadmium in river sediments. Studies of trace element remobilisation performed with natural river sediments are however difficult to interpret due to the complex composition of the medium (presence of several interacting trace elements, numerous mineral phases and mixed pollution). We then decided to work with a simplified synthetic sediment. Such an approach has been previously explored by Kheboian and Bauer [17] to investigate sequential extraction procedures and solid speciation of trace elements. In our study, experiments were performed to assess the involvement of microbial activity on $\mathrm{Cd}$ dissolution using synthetic $\mathrm{Cd}$ hydroxyapatite in which the physico-chemical occurrence of $\mathrm{Cd}$ is well known and with pure cellulose as organic substrate.

\section{Materials and methods}

\subsection{Synthetic sediment preparation and experimental design}

The sediment was prepared by mixing synthetic hydroxyapatite and quartz sand, (Denain Anzin Minéraux) dry-ground and sieved to a particle size $<53 \mu \mathrm{m}$. Cd-substituted hydroxyapatite was graciously provided by Dr. B. Gerardin (personal communication: patent in agreement procedure). A nonsubstituted apatite was also synthetized to provide a 
non-polluted reference sediment. In both cases, $\mathrm{X}$-ray diffraction spectra demonstrated the presence of a true hydroxyapatite phase.

The culture medium for microorganisms was a modified cellulolytic medium, phosphorus and calcium free, containing: $\mathrm{NaCl}, 0.125 \mathrm{~g} \cdot \mathrm{l}^{-1}$, $\mathrm{NH}_{4} \mathrm{NO}_{3}, 1 \mathrm{~g} \cdot \mathrm{l}^{-1}$, yeast extract, $0.1 \mathrm{~g} \cdot \mathrm{l}^{-1}$, bacto peptone, $0.1 \mathrm{~g} \cdot \mathrm{l}^{-1}$, and cellulose, $5 \mathrm{~g} \cdot \mathrm{l}^{-1}$. Cellulose, obtained from shredded filter papers (Whatman 40), was chosen as a reference plant material present in natural sediment. Indeed most previous studies dealing with microbial weathering and organic matter mineralisation have focussed on simple organic compounds (sugars as glucose, aminoacids, etc.) rather than on complex organic matter such as plant polymers (e.g. cellulose) or humic substances [2, 14].

$10 \mathrm{~g}$ of synthetic sediment described in Table I were placed in a $250 \mathrm{ml}$ plasma bottle to obtain a final $\mathrm{Cd}$ concentration of $20 \mu \mathrm{g} \cdot \mathrm{g}^{-1}$. $100 \mathrm{ml}$ of liquid culture medium were added and the flasks were sealed hermetically with a rubber stopper maintained with an aluminium cap. Sterilisation was obtained by autoclaving twice $\left(120^{\circ} \mathrm{C}\right.$ for $20 \mathrm{~min}$ at $48 \mathrm{~h}$ interval). Both organic and mineral phases were unaffected by autoclaving, except for a slight $\mathrm{Cd}$ solubilisation of $0.55 \%$ total $\mathrm{Cd}$.

The mixed microflora used in the experiments, originated from a natural river sediment (La Rosselle river, France). The inoculum was prepared by dispersing $10 \mathrm{~g}$ of sediment sample in $90 \mathrm{ml}$ of $\mathrm{NaCl}$ sterile solution $\left(8.5 \mathrm{~g} \cdot \mathrm{l}^{-1}\right)$ for $1 \mathrm{~h}$. Serial dilutions were then carried out and the inoculum $(10 \mathrm{ml} /$ flask) was provided by the $10^{-3}$ sediment suspension. Experiments were performed in the presence or absence of microorganisms, i.e. under biotic (inoculated with microorganisms) or abiotic conditions (sterile conditions). The synthetic sediments

Table I. Composition of synthetic sediments (CdHA: Cd-substituted hydroxyapatite; HA: non-substituted hydroxyapatite).

\begin{tabular}{lcccc}
\hline Sediment & $\begin{array}{c}\text { Quartzic } \\
\text { sand } \\
(\mathrm{g})\end{array}$ & $\begin{array}{c}\text { Hydroxy- } \\
\text { apatite } \\
(\mathrm{mg})\end{array}$ & $\begin{array}{c}\mathrm{Cd} \\
\left(\mu \mathrm{g} \cdot \mathrm{g}^{-1}\right. \\
\text { of }\end{array}$ & $\begin{array}{c}\text { Sediment }) \\
(\mathrm{mg})\end{array}$ \\
\hline CdHA & 10 & 5.3 & 20 & 500 \\
HA & 10 & 5.3 & 0 & 500 \\
\hline
\end{tabular}

were incubated aerobically in the dark at $28{ }^{\circ} \mathrm{C}$ on a horizontally stating shaker for 53 days. The plasma bottles were periodically opened to renew the atmosphere under a sterile laminar flow hood for $1 \mathrm{~h}$. All treatments were conducted with five replicates.

\subsection{Sample characterisation}

Organic matter mineralisation was followed by the $\mathrm{CO}_{2}$ evolved during incubation. Periodically, a $4 \mathrm{ml}$ sample of the flask's headspace was collected with a syringe and analysed for its $\mathrm{CO}_{2}$ content with a Binos 1004 infrared spectrophotometer.

Supernatants were collected with a $10 \mathrm{ml}$ syringe at days $0,12,25$ and 53, filtered through $0.22 \mu \mathrm{m}$ cellulose membranes (Micron Separation Inc.), and analysed for their mineral and organic contents. $\mathrm{pH}$ was measured in each replicate with a Tacussel $\mathrm{pH}-$ meter (PHN-850). Nitrate and ammonium contents were determined by ionic chromatography and by colorimetry (Nessler method, Merck), respectively. $\mathrm{Cd}, \mathrm{Ca}, \mathrm{P}$ and Si contents were assessed with inductively-coupled plasma atomic emission spectrometry (Jobin Yvon 238).

Dissolved organic carbon was measured using a total carbon analyser (Dohrmann DC190). Organic acids contained in the supernatant were identified by high performance liquid chromatography (Gold Beckman system) equipped with a UV detector set at $200 \mathrm{~nm}$ (Aminex HPX-87H anion exchange column under isocratic conditions).

\subsection{Transmission electron microscopy and elemental analysis}

After 53 days of incubation, most of the sediment was freeze-dried, while a portion of fresh material was embedded in an expoxy resin. The freeze-dried sediment was re-suspended in ethanol under ultrasonication, then a drop of suspension was evaporated on a carbon-coated copper grid for observation. Resin-embedding was carried out after fixation of the sediment with glutaraldehyde $2 \%$ and osmium tetroxide $2 \%$, and dehydration in a graded serie of acetone [29]. Ultrathin sections (less than $1000 \AA$ thick) were cut with an ultramicrotome (Reichert 
OM U2), placed on copper grids, and stained with uranyl acetate and lead citrate to enhance the resolution of natural organic matter [25].

TEM examination was carried out with a Transmission Electron Microscope (Phillips CM 20) operated at an accelerating voltage of $200 \mathrm{kV}$. The microscope was equipped with an EDS energy dispersive X-ray spectrometer and provided elemental analysis of particles.

\subsection{Statistical analysis}

Data were analysed by ANOVA or Student's t-test using STATVIEW software (Abacus Concepts, Inc.). The significance of differences between treatments was tested at a $5 \%$ probability level.

\section{Results}

\subsection{Cellulose biodegradation and microbial activity}

Figure 1 shows the cellulose mineralisation rate as a function of incubation time for both synthetic sediments respectively with (CdHA) and without $\mathrm{Cd}$ (HA) in biotic and abiotic conditions. In controls (abiotic samples) $\mathrm{CO}_{2}$ production was low, and this was attributed to chemical phenomena. Sterility in these treatments, verified by inoculation on standard nutrient solid media, was preserved except for

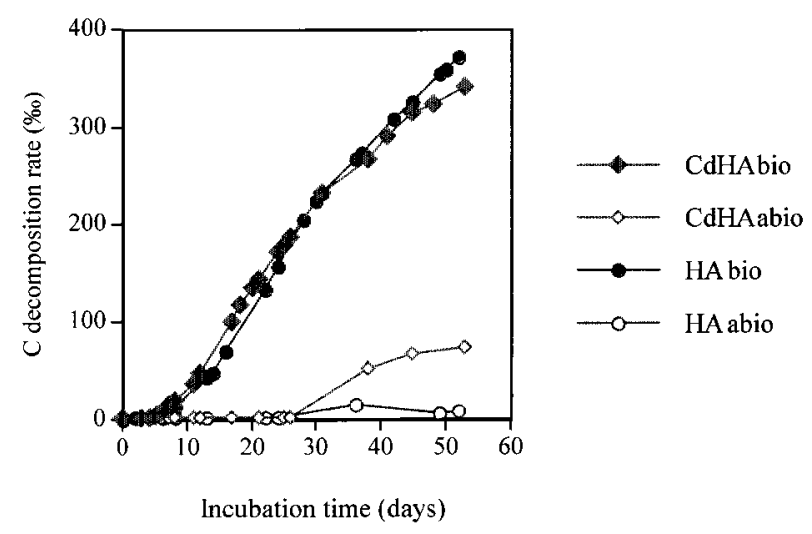

Figure 1. Cellulose mineralisation rate in synthetic sediments (CdHA and HA), in the presence (bio) or absence (abio) of microorganisms, during 53 -days of incubation at $28^{\circ} \mathrm{C}$. one replicate. Inoculated treatments released significant amounts of $\mathrm{CO}_{2}$ from cellulose mineralisation. A lag period of about 6 days was observed at the beginning of incubation, irrespective of the presence of $\mathrm{Cd}$. The mineralisation rate then displayed a strong increase for 30 days without reaching a stationary phase at the end of the experiment. Total $\mathrm{CO}_{2}$ evolved corresponded to $33.9 \%$ and $37.2 \%$ of cellulose $\mathrm{C}$ added to CdHA and HA synthetic sediments, respectively.

HPLC revealed the presence of trace amounts of carboxylic aliphatic acids (succinic and pyruvic acids) in biotic conditions. Reducing sugars were also detected in amounts close to $114 \mathrm{mg}$ of equivalent glucose per litre, which corresponds to $34 \%$ of soluble organic carbon. All these metabolic compounds originated from cellulose biodegradation.

\section{2. pH evolution of the medium}

The temporal evolution of $\mathrm{pH}$ in inoculated treatments was significantly different from those observed in non-inoculated controls (Fig. 2). All abiotic samples showed a constant $\mathrm{pH}$ close to 6.7 with a non-significant slight decrease at the end of incubation time for Cd-substituted hydroxyapatite sediments. In contrast, in the presence of microorganisms, the $\mathrm{pH}$ of CdHA sediments decreased strongly to 4.5 at day 25 and remained constant thereafter. Sediments containing non-substituted hydroxyapatite (HA sediment) showed a similar

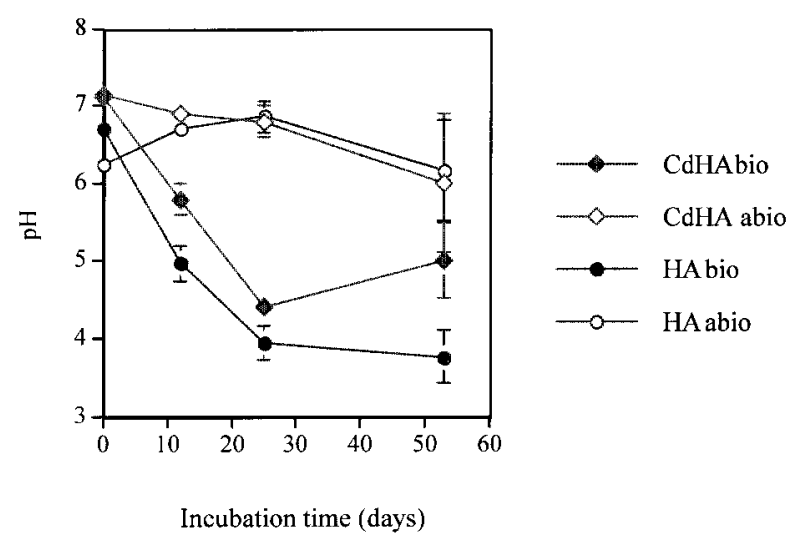

Figure 2. Change in $\mathrm{pH}$ in the medium during aerobic incubation of Cd-substituted hydroxyapatite (CdHA) and non-substituted hydroxyapatite (HA), in the presence (bio) or absence (abio) of microorganisms. 
trend, with a lower final $\mathrm{pH}$ equal to 3.8 at day 25 . Statistical analysis demonstrated that $\mathrm{pH}$ values measured for CdHA and HA sediments in biotic conditions were different.

\subsection{Release of $\mathrm{Cd}$ and major elements}

ICP measurements revealed that $\mathrm{Si}$ content of supernatants in all biotic and abiotic treatments did not vary significantly after autoclaving, and remained close to $300 \mu \mathrm{g} \cdot \mathrm{g}^{-1}$ of sediment. Si concentration in the liquid medium was close to $30 \mathrm{mg} \cdot \mathrm{l}^{-1}$ during incubation. Likewise, no further significant release of $\mathrm{Ca}, \mathrm{P}$, and $\mathrm{Cd}$, was observed for abiotic controls after sterilisation (Figs. 3 and 4).

In contrast, the presence of microorganisms resulted in an increased solubilisation of $\mathrm{Cd}$ and $\mathrm{Ca}$ in CdHA sediment, while $\mathrm{P}$ concentration decreased (Fig. 3). Thus, $\mathrm{Ca}$ and $\mathrm{Cd}$ solubilisation increased from $52.4 \mu \mathrm{g} \cdot \mathrm{g}^{-1}$ and $0.073 \mu \mathrm{g} \cdot \mathrm{g}^{-1}$ of sediment at day 0 to reach $157 \mu \mathrm{g} \cdot \mathrm{g}^{-1}$ and $6.95 \mu \mathrm{g} \cdot \mathrm{g}^{-1}$ of sediment at day 25, respectively (Fig. 3). From 25 to 53 days of incubation, no further solubilisation of $\mathrm{Ca}$ and $\mathrm{Cd}$ was observed, although organic matter biodegradation carried on. The final $\mathrm{Ca}$ and $\mathrm{Cd}$ concentrations in the liquid medium were $20.6 \mathrm{mg} \cdot \mathrm{l}^{-1}$ and $0.897 \mathrm{mg} \cdot \mathrm{l}^{-1}$, respectively. This corresponded to a $34 \mathrm{wt} \%$ solubilisation of initial $\mathrm{Cd}$ and a $55 \mathrm{wt} \%$ solubilisation of initial $\mathrm{Ca}$ from hydroxyapatite. Cd release was closely correlated with Ca solubilisation $\left(\mathrm{r}^{2}=0.90\right)$, in relation with its crystallochemical position of Ca substitution.

For non-substituted hydroxyapatite (HA sediment) in the presence of microorganisms (Fig. 4),

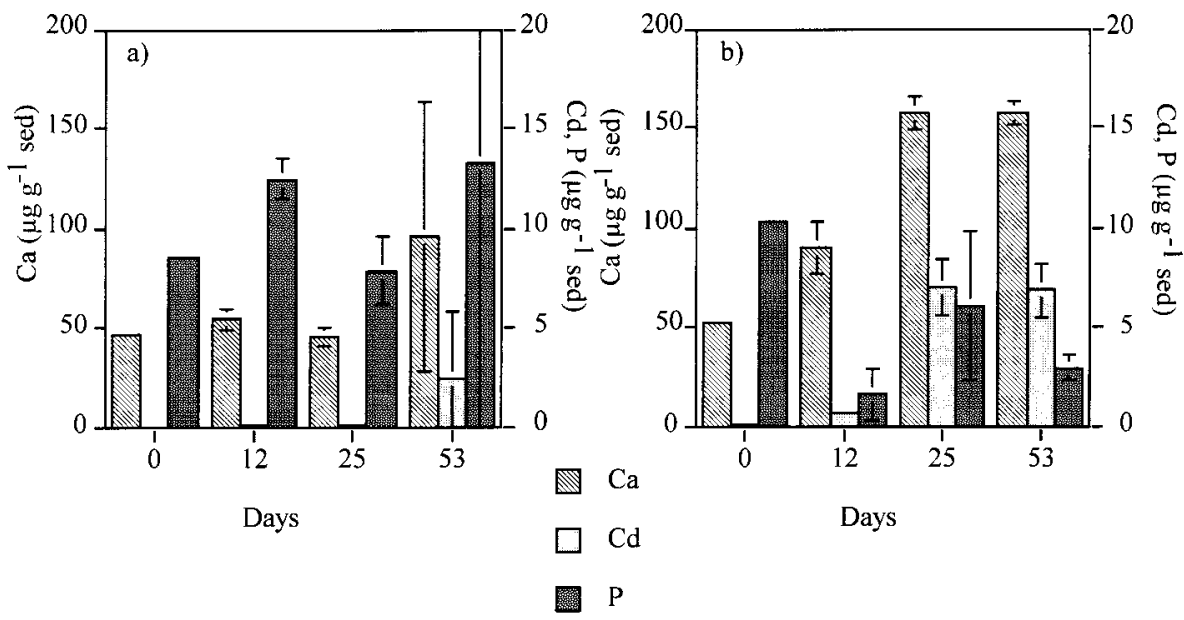

Figure 3. Amounts of solubilised $\mathrm{Ca}$, $\mathrm{Cd}$ and $\mathrm{P}$ in (a) controls and (b) biotic treatments during incubation of $\mathrm{CdHA}$ sediment.

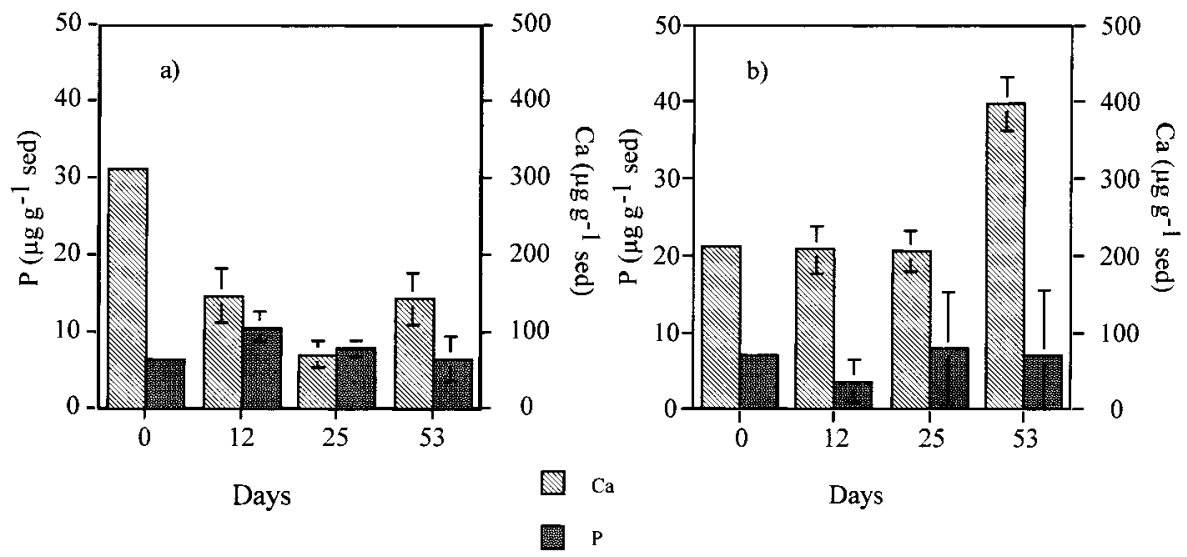

Figure 4. Amounts of solubilised $\mathrm{Ca}$ and $\mathrm{P}$ in (a) abiotic and (b) biotic treatments during incubation of HA sediment. 
$\mathrm{Ca}$ amount in solution remained constant and close to $205 \mu \mathrm{g} \cdot \mathrm{g}^{-1}$ of sediment up to day 25 , with a significant increase to $407 \mu \mathrm{g} \cdot \mathrm{g}^{-1}$ of sediment at the end of incubation (day 53). P concentration was about $8 \mu \mathrm{g} \cdot \mathrm{g}^{-1}$ throughout the experiment for both biotic and abiotic treatments.

\subsection{TEM observations and microanalysis}

Electron micrographs revealed that initial ordered Cd-substituted hydroxyapatite was organised as aggregates of lath-like elementary particles, $50 \mathrm{~nm}$ in length and $5 \mathrm{~nm}$ in thickness (Fig. 5a). Shape of crystallites and texture of aggregates were not affected by autoclaving. In contrast, microbial activity after 53 days strongly corroded the elemen- tary particles which appeared very spongy (Fig. 5b).

EDS microanalysis indicated that initial Cd-substituted hydroxyapatite presented a $(\mathrm{Ca}+\mathrm{Cd}) / \mathrm{P}$ elemental ratio equal to 1.59 , consistent with a stoechiometric apatite having a $\mathrm{Cd}$ for $\mathrm{Ca}$ substitution, and that it was free of $\mathrm{Cl}$. Cd elemental concentration was about $1.5 \%$ (Tab. II and Fig. 6). Microanalysis also revealed that autoclaving at $120{ }^{\circ} \mathrm{C}$ did not alter hydroxyapatite stoechiometry. The average $(\mathrm{Ca}+\mathrm{Cd}) / \mathrm{P}$ elemental ratio slightly increased to 1.65 after microbial weathering, whereas $\mathrm{Cd}$ atomic percentage diminished to 1.3. Surprisingly, EDS spectra of weathered apatite revealed also the presence of $0.2 \%$ of iron which was identified as originating from cellulose fibers
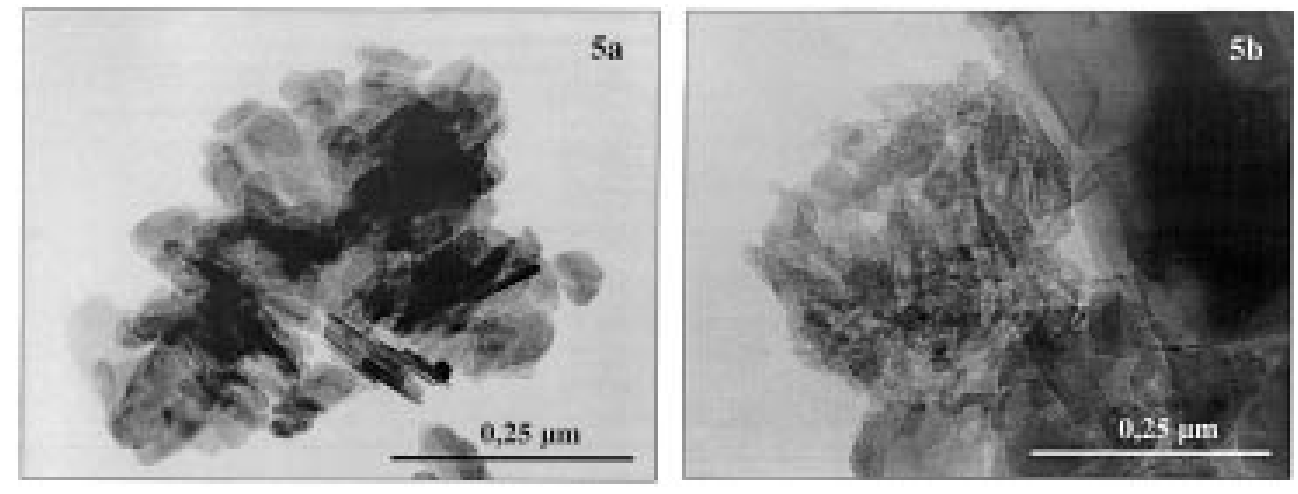

Figure 5. TEM micrographs of Cd-substituted hydroxyapatite before $(5 a)$ and after (5b) microbial weathering.
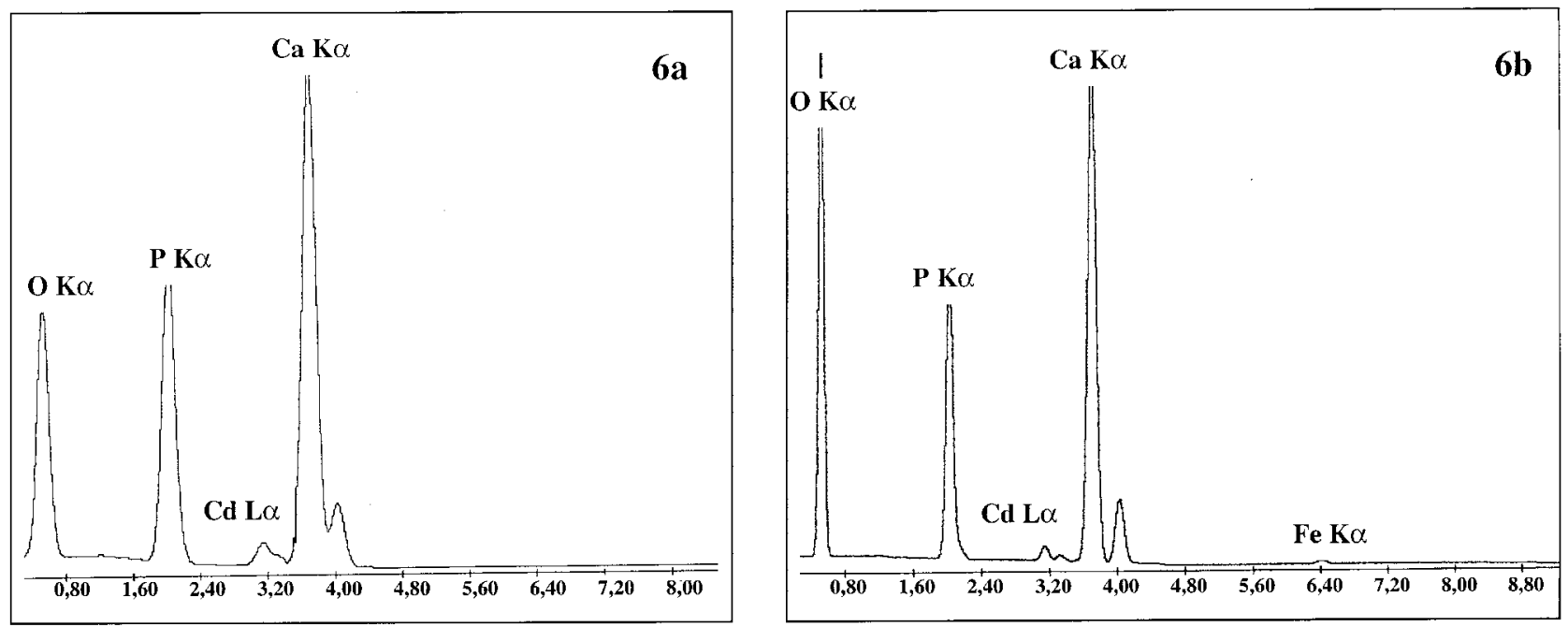

Figure 6. EDS spectra of initial Cd-apatite (6a) and microbial weathered Cd-apatite (6b). 
Table II. EDS elemental analysis of Cd-substituted hydroxyapatite, before and after microbial weathering.

\begin{tabular}{ccc}
\hline Cd-substituted apatite & Initial (atomic \%) & Final (atomic \%) \\
\hline Ca & 20.7 & 14.4 \\
Cd & 1.5 & 1.3 \\
P & 14.0 & 9.5 \\
O & 63.9 & 74.7 \\
$(\mathrm{Ca}+\mathrm{Cd}) / \mathrm{P}$ & 1.59 & 1.65 \\
\hline
\end{tabular}

polluted during shredding. Electron diffraction patterns confirmed the nature of hydroxyapatite after weathering.

Figure 7 shows a typical electron micrograph of resin-embedded $\mathrm{CdHA}$ sediment at day 53. It can be underlined that $\mathrm{Cd}$ hydroxyapatite aggregates were found in contact with microorganisms. A thick and contrasted exopolymeric layer surrounded the microorganisms which showed no detectable adsorbed $\mathrm{Cd}$ on cell walls nor on exopolymers by EDS analysis.

\section{Discussion}

In the present experiments, it was demonstrated that aerobic microbial degradation of cellulose can have a significant effect and be involved in the dissolution and weathering of substituted and non-substituted hydroxyapatites.

Analysis of supernatants from biotic treatments in the presence of substituted hydroxyapatite showed high levels of solubilised cadmium and calcium, that reached $34 \%$ of the total $\mathrm{Cd}$ and $55 \%$ of the total $\mathrm{Ca} . \mathrm{Ca} / \mathrm{P}$ ratios imply that the $\mathrm{P}$ deficit in solution was due to its consumption by microorganisms. Si was unaffected by solubilisation processes. In addition, a significant correlation between $\mathrm{Cd}$ and $\mathrm{Ca}$ in solution and $\mathrm{pH}$, i.e. proton release, was observed.

Organic acids produced during cellulose biodegradation were only detected in trace amounts. They are probably easily metabolised by microbial communities, so that they can not be considered as acidifying and solubilising agents. These results suggest that the $\mathrm{Cd}$ and $\mathrm{Ca}$ solubilisation process was a consequence of the observed acidification.

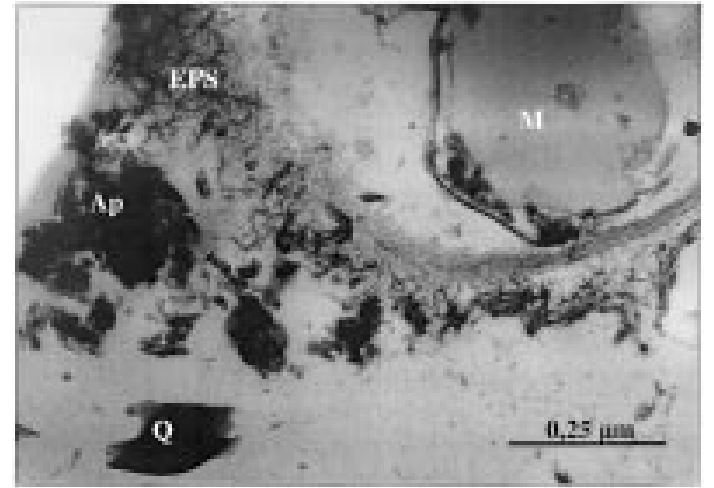

Figure 7. TEM micrograph of resin-embedded synthetic sediment; Ap: Cd-hydroxyapatite; Q: quartz particle; M: microorganism; EPS: exopolymeric substances.

The $\mathrm{pH}$ decrease may be due to proton extrusion upon $\mathrm{NH}_{4}$ uptake from $\mathrm{NH}_{4} \mathrm{NO}_{3}$ in the culture medium, as has been already observed by Illmer and Schinner for solubilisation of phosphate rocks in the presence of various bacteria strains [16]. Spot analyses of samples from HA sediment revealed a decrease of ammonium in biotic experiments thus demonstrating a $\mathrm{NH}_{4}{ }^{+}$uptake by microorganisms. On the other hand, nitrate remained constant during incubation implying no nitrification. This solubilisation mechanism due to an ammonium consumption was also suspected in the case of zinc phosphate dissolution process by Pseudomonas fluorescens [11]. Furthermore, it has been shown that the presence of ammonium is the main parameter involved in phosphate solubilisation for two Penicillium species in relation with their nutrition and $\mathrm{NH}_{4}^{+} / \mathrm{H}$ exchange phenomenon [3].

As revealed by HA experiments that show a similar $\mathrm{CO}_{2}$ evolution to $\mathrm{CdHA}$, Cd release did not affect the total microbial mineralisation, but seemed to attenuate the $\mathrm{pH}$ decrease (i.e. ammonium uptake). Thus Cd may have an effect on microbial processes related to nitrogen uptake and nutrition.

The very low content in simple organic acids indicated that solubilised $\mathrm{Cd}$ is associated to other anionic ligands (e.g. nitrate or fulvic-like compounds) or present as free form. These species and especially the free divalent ion are known to be the most toxic forms in soil solution for microorganisms $[22,27]$. 
This microbial weathering process does not affect preferentially some mineralogical properties, and the residual mineral is always detected as hydroxyapatite. The final ratios of $\mathrm{P}, \mathrm{Ca}$ and $\mathrm{Cd}$ in solution suggest a preferential precipitation in the order of $\mathrm{P}>\mathrm{Ca}>\mathrm{Cd}$. The presence of $\mathrm{Fe}$ can also promote phosphate precipitation.

\section{Conclusion}

Our experiments showed that aerobic microorganisms, when nutrients, energy and carbon sources are available such as cellulolytic material, are involved in organic matter biodegradation and are indirectly responsible of solubilisation of major and trace elements such as $\mathrm{Ca}$ and $\mathrm{Cd}$. Thus a moderatly degradable organic matter input may promote biological $\mathrm{Cd}$ release from hydroxyapatite phases present in river sediments. Under such conditions, hydroxyapatites must be considered only as temporary trapping phases for heavy metals present in the mineral lattice.

The ability of heterotrophic microorganisms to solubilise heavy metals as $\mathrm{Cd}$ must be considered in the definition of risk assessment in relation with environmental conditions especially nutrient input, Eh and $\mathrm{pH}$ evolution, metabolic production. Our approach provided a model to study mineral weathering and metal mobilisation. Extrapolation to field observations need some complementary experiments to confirm laboratory results.

Acknowledgments: This work was supported by a grant from the MENRT and the Agence de l'Eau Rhin-Meuse. The authors would like to thank J.H. Rouiller for help with the ICP-AES measurements.

\section{References}

[1] Adriano D.C., Trace elements in the terrestrial environment, Springer-Verlag, New York, 1986.

[2] Andreux F., Boudot J.-P., Choné T., Gueniot B., Relation entre la biodégradation de la glycine libre ou combinée et la nature du complexe d'altération des sols, Agronomie 3 (1983) 247-257.

[3] Asea P.E.A., Kucey R.M.N., Stewart J.W.B., Inorganic phosphate solubilization by two Penicillium species in solution culture and soil, Soil Biol. Biochem. 20 (1988) 459-464.
[4] Berthelin J., Microbial weathering processes in natural environments, in: Lerman A., Meybeck M. (Eds.), Physical and Chemical Weathering in Geochemical Cycles, Kluwer Academic Press, London, 1988, pp. 33-59.

[5] Berthelin J., Interactions entre microorganismes du sol et éléments métalliques en traces, in: Qualité et Conservation des Sols, Devenir des Polluants dans les Sols, Collection Recherche et Environnement, Vol. 34, Ministère de l'Environnement, Paris, 1989, pp. 157-181.

[6] Berthelin J., Munier-Lamy C., Leyval C., Effect of microorganisms on mobility of heavy metals in soils, in: Huang P.M., Berthelin J., Bollag J.-M., McGill W.B., Page A.L. (Eds.), Environmental impact of soil component interactions, Vol. 2, Metals, other inorganics, and microbial activities, CRC Press, 1995, pp. 3-17.

[7] Bourrelier P.-H., Berthelin J., Contamination des sols par les éléments en traces : les risques et leur gestion, Rapport n ${ }^{\circ} 42$ Académie des Sciences, TEC\&DOCLavoisier, Paris, 1998.

[8] Brooks P.C., McGrath S.P., Effects of metal toxicity on the size of the soil microbial biomass, J. Soil Sci. 35 (1984) 341-346.

[9] Chanmugathas P., Bollag J.M., Microbial mobilization of cadmium in soil under aerobic and anaerobic conditions, J. Environ. Qual. 16 (1987) 161-167.

[10] Delon J.F., Yvon J., Berthelin J., Belgy G., Marchand S., Landais P., Elie M., Faure P., Kruge M., Langlois E., Étude du statut de polluants minéraux et organiques dans les sédiments et les suspensions de trois rivières lorraines, Rapport de Contrat Agence de l'Eau Rhin-Meuse, 1996.

[11] Di Simine C.D., Sayer J.A., Gadd G.M., Solubilization of zinc phosphate by a strain of Pseudomonas fluorescens isolated from a forest soil, Biol. Fertil. Soils 28 (1998) 87-94.

[12] Ehrlich H.L., Geomicrobiology, 3rd ed., Marcel Dekker Inc., New York, 1996.

[13] Gadd G.M., Influence of microorganisms on the environmental fate of radionuclides, Endeavour 20 (1996) 150-156.

[14] Gale P.M., Reddy K.R., Graetz D.A., Mineralization of sediment organic matter under anoxic conditions, J. Environ. Qual. 21 (1992) 394-400.

[15] Galvin R.M., Occurrence of metals in waters: an overview, Water SA 22 (1996) 7-18.

[16] Illmer P., Schinner F., Solubilization of inorganic phosphates by microorganisms isolated from forest soils, Soil Biol. Biochem. 24 (1992) 389-395. 
[17] Kheboian C., Bauer C.F., Accuracy of selective extraction procedures for metal speciation in model aquatic sediments, Anal. Chem. 59 (1987) 1417-1423.

[18] Leyval C., Berthelin J., Weathering of mica by roots and rhizospheric microorganisms of pine, Soil Sci. Soc. Am. J. 55 (1991) 1009-1016.

[19] Macklin M.G., Dowsett R.B., The chemical and physical speciation of trace metals in fine grained overbank flood sediments in the Tyne basin, north-east England, Catena 16 (1989) 135-151.

[20] McBride M.B., Environmental chemistry of soils, Oxford University Press, New York, 1994.

[21] McGrath S.P., Chaudri A.M., Giller K.E., Longterm effects of metals in sewage sludge on soils, microorganisms and plants, J. Ind. Microbiol. 14 (1995) 94-104.

[22] McLaughlin M.J., Singh B.R., Cadmium in soils and plants, Kluwer Academic Publishers, The Netherlands, 1999.

[23] Nriagu J.O., Human influence on the global cycling of trace elements, in: Farmer J.C. (Ed.), Heavy metals in the environment, CEP Consultants Ltd, Edinburgh, 1991, pp. 1-5.

[24] Nriagu J.O., Sprague J.B., Cadmium in the aquatic environment, Wiley, New York, 1987.
[25] Reynolds E., The use of lead citrate at high $\mathrm{pH}$ as an electron opaque stain in electron microscopy, J. Cell. Biol. 17 (1963) 176-191.

[26] Robert M., Berthelin J., Role of biological and biochemical factors in soil mineral weathering, in: Soil Science Society of America, Interactions of soil minerals with natural organics and microbes, SSSA Spec. Pub. $\mathrm{n}^{\circ} 17$, Madison, 1986, pp. 453-495.

[27] Sauvé S., Dumestre A., McBride M., Hendershot W., Derivation of soil quality criteria using predicted chemical speciation of $\mathrm{Pb}^{2+}$ and $\mathrm{Cu}^{2+}$, Environ. Toxicol. Chem. 17 (1998) 1481-1489.

[28] Tack F.M.G., Verloo M.G., Chemical speciation and fractionation in soil and sediment heavy metal analysis: a review, Int. J. Environ. Anal. Chem. 59 (1995) 225-228.

[29] Villemin G., Toutain F., Méthode de fixation d'échantillons organo-minéraux de sols pour la microscopie électronique à transmission, in: Fedoroff N., Bresson L.M., Courty M.A. (Eds.), Micromorphologie des sols, AFES, 1987, pp. 43-48. 